\title{
Optics-based surveys of large unicellular zooplankton: a case study on radiolarians and phaeodarians
}

\author{
Yasuhide Nakamura, ${ }^{1, *}$, Rei Somiya ${ }^{2}$, Noritoshi Suzuki ${ }^{3}$, Mitsuko Hidaka-Umetsu $^{4,5}$, \\ ATSUSHI YAMAGUCHI ${ }^{6} \&$ DHUGAL J. LindSAY ${ }^{4,5}$ \\ ${ }^{1}$ Department of Botany, National Museum of Nature and Science, Tsukuba 305-0005, Japan \\ ${ }^{2}$ Graduate School of Fisheries and Environmental Sciences, Nagasaki University, Nagasaki 852-8521, Japan \\ ${ }^{3}$ Department of Earth Science, Graduate School of Science, Tohoku University, Sendai 980-8578, Japan \\ ${ }^{4}$ Research and Development (R\&D) Center for Submarine Resources, Japan Agency for Marine-Earth Science and Technology \\ (JAMSTEC), Yokosuka 237-0061, Japan \\ ${ }^{5}$ School of Marine Biosciences, Kitasato University, Sagamihara 252-0373, Japan \\ ${ }^{6}$ Graduate School of Fisheries Sciences, Hokkaido University, Hakodate 041-8611, Japan
}

Received 24 May 2016; Accepted 6 February 2017 Responsible Editor: Akihiro Tuji

\begin{abstract}
Optics-based surveys for large unicellular zooplankton were carried out in five different oceanic areas. New identification criteria, in which "radiolarian-like plankton" are categorized into nine different groups, are proposed for future optics-based surveys. The autonomous visual plankton recorder (A-VPR) captured 65 images of radiolarians (three orders: Acantharia, Spumellaria and Collodaria) and 117 phaeodarians (four taxa: Aulacanthidae, Phaeosphaerida, Tuscaroridae and Coelodendridae). Colonies were observed for one radiolarian order (Collodaria) and three phaeodarian taxa (Phaeosphaerida, Tuscaroridae and Coelodendridae). The rest of the radiolarian orders (Taxopodia and Nassellaria) and the other phaeodarian taxa were not detected because of their small cell size ( $<$ ca. $400 \mu \mathrm{m})$.
\end{abstract}

Key words: Phaeodaria, protist, Radiolaria, VPR, zooplankton

\section{Introduction}

In recent years, optics-based surveys on marine organisms have become more common, thanks to the development of tools such as the In Situ Ichthyoplankton Imaging System (ISIIS), Underwater Video Profiler (UVP), visual plankton recorder (or video plankton recorder, VPR), and others (see review by Benfield et al. 2007). Such methods allow us to investigate marine multicellular plankton (e.g., copepods, pteropods, larvaceans and jellyfish) at ecologically meaningful scales (Benfield et al. 1996, Remsen et al. 2004, Jacobsen \& Norrbin 2009). Optics-based surveys are also optimal for the observation of unicellular plankton possessing fragile siliceous skeletons, which are often fragmented and broken by sampling with a plankton net, with the result that their ecology (e.g. formation of colonies?) has not yet been well-clarified.

In conventional optics-based studies, plankton of round

*Corresponding author: Yasuhide Nakamura; E-mail, jasnakamura@ kahaku.go.jp shape are often simply classified as "Radiolaria". Radiolarians, however, include five orders (Acantharia, Spumellaria, Collodaria, Nassellaria and Taxopodia), and the skeletal components and ecology differ among the orders, meaning that the ecological role of each order is significantly different (Suzuki \& Not 2015). The order Spumellaria, possessing a skeleton made of amorphous silica, is solitary and their biomass is usually low (Suzuki \& Not 2015). On the contrary, Collodaria, which also have siliceous skeletons in general, contain many colonial species, and this order sometimes exhibits high biomass (Dennett et al. 2002, Biard et al. 2016). Another radiolarian order, Acantharia, has a skeleton mainly composed of strontium sulfate, and therefore this order is known to contribute to the strontium cycle in the oceans (Suzuki \& Aita 2011b, Decelle \& Not 2015). Phaeodaria have siliceous skeletons, and their overall appearance is similar to that of radiolarians. Yet, molecular studies have revealed that this group is phylogenetically different from Radiolaria (Nikolaev et al. 2004, Polet et al. 2004, Sierra et al. 2013, Nakamura et al. 2015). Phaeodarians now belong to the phylum Cercozoa, 


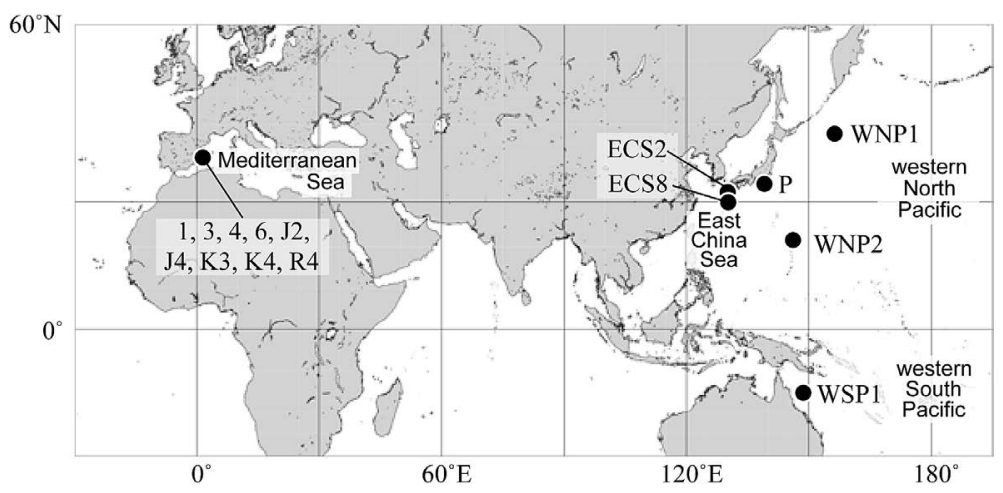

Fig. 1. Location of the sampling stations for the present optics-based surveys.

included in Rhizaria (SAR), together with Radiolaria and Foraminifera (Howe et al. 2011, Adl et al. 2012). The cell size of large phaeodarians can exceed $500 \mu \mathrm{m}$ in diameter, and they occasionally exhibit high biomasses. Large phaeodarians have been reported to comprise up to $22.3 \%$ of the total zooplankton biovolume in the Sea of Japan (Nakamura et al. 2013), and $2.7-13.7 \%$ in the western North Pacific (Steinberg et al. 2008). It is, therefore, suggested that these unicellular zooplankton can play an important role in the silica cycle and the ecosystem in the oceans (Riemann 1989, Lampitt et al. 2009, Nakamura \& Suzuki 2015a, b). Phaeodarians and collodarians are the most important contributors to the biomass of Rhizaria, which has been estimated to comprise $33 \%$ of the total zooplankton abundance worldwide (Biard et al. 2016).

The vertical distribution also differs among the groups. Since acantharians, collodarians and a subset of spumellarians have algal symbionts, their distribution is thought to be predominantly in the euphotic zone, in order to photosynthesize efficiently (Antia et al. 1993, Michaels 1988, Suzuki \& Aita 2011a, Suzuki \& Not 2015). In contrast, no phaeodarians possess algal symbionts, and they are considered to dwell also in deeper zones and to have a more extensive vertical distribution (Reshetnyak 1966). The precise pattern of their vertical distribution is, however, still largely unknown because of the difficulty of catching them undamaged in plankton nets.

Most plankton studies have focused on multicellular zooplankton with large body sizes (e.g. copepods and other crustaceans) and unicellular phytoplankton that cause serious environmental problems (e.g. harmful algal blooms). Therefore, unicellular zooplankton, such as radiolarians and phaeodarians, have been largely ignored. However, studies on such unicellular plankton are important from the viewpoint of the material cycle and understanding ecosystems in the oceans (Biard et al. 2016), as explained above. We, hence, focus here on the unicellular plankton that have usually been classified simply as "Radiolaria" in previous optics-based surveys, examine their ecology, and construct identification criteria for use in optics-based plankton studies.

\section{Materials and Methods}

VPR surveys were conducted in the five different oceanic areas indicated in Fig. 1: western North Pacific (stas. WNP1, WNP2); northern East China Sea (stas. ECS2 and ECS8 to the west of Kagoshima, Japan); western South Pacific (sta. WSP1 near Osprey Reef in the Coral Sea, Australia) and western Mediterranean Sea (stas. 1, 3, 4, 6, J2, J4, K3, K4 and R4 in the Balearic Sea). The VPR images were taken at the stations shown in Table 1 (except sta. P) using an Autonomous Visual Plankton Recorder (A-VPR), according to the procedure explained in Lindsay et al. (2014). The A-VPR is composed of a digital camera (UNIC UC-1830CL, 2/3 inch interline CCD, Canon J10x10R-II Lens-modified) in a pressure housing rated to $1,000 \mathrm{~m}$ depth and which records $1028 \times 1024$ pixel color images, compressed and stored on a hard drive as JPEG 2000 files at a rate of $12-15 \mathrm{~Hz}(150 \mathrm{~kb} / \mathrm{image})$. The field of view was set to $43 \mathrm{~mm} \times 43 \mathrm{~mm}$. Darkfield illumination is provided by a ring strobe (Perkin-Elmer FX4400, 1 joule/flash), and photographs are linked to CTD (Citadel CTD-NV, Teledyne RD Instruments, FSI NIXC CTD Auto-7000 m) data to give environmental information about depth, water temperature and salinity for the plankton and particles in each photo. High-definition video footage was also recorded at sta. P by an HDTV (High-Definition TeleVision) camera deployed on the ROV (Remotely-Operated Vehicle) $H y$ per-Dolphin (Table 1). The HDTV camera integrated an ultra-sensitive super HARP (High gain Avalanche Rushing Photo-conductor) tube, and the camera sensitivity was F1.8 at 2 lux, gain was variable at 4 to 200 times, the signal to noise ratio was $43 \mathrm{~dB}$ and resolution was $800 \mathrm{TV}$ lines. The unicellular zooplankton in all of the above images were identified according to their morphological characteristics, referring to the current classification system of radiolarians and phaeodarians (Takahashi \& Anderson 2002 for phaeodarians, Matsuzaki et al. 2015 and Suzuki \& Not 2015 for radiolarians). 
Table 1. Detailed information on the stations where the optics-based surveys were conducted in this study.

\begin{tabular}{|c|c|c|c|c|c|c|c|c|c|}
\hline \multirow{2}{*}{ sea area } & \multirow{2}{*}{ cruise name (vessel) } & \multirow{2}{*}{ season } & \multirow{2}{*}{ station } & \multirow{2}{*}{ lat. } & \multirow{2}{*}{ long. } & \multirow{2}{*}{$\begin{array}{l}\text { surveyed } \\
\text { depth (m) }\end{array}$} & \multicolumn{3}{|c|}{ no. of VPR images } \\
\hline & & & & & & & total & Radiolaria & Phaeodaria \\
\hline \multirow[t]{4}{*}{ western North Pacific } & MR11-03 (R/V Mirai) & April, 2011 & WNP1 & $47^{\circ} 00^{\prime} \mathrm{N}$ & $160^{\circ} 04^{\prime} \mathrm{E}$ & $0-395$ & 1,652 & 1 & 20 \\
\hline & & & & & & & 567 & 0 & 28 \\
\hline & & & WNP2 & $20^{\circ} 59^{\prime} \mathrm{N}$ & $145^{\circ} 01^{\prime} \mathrm{E}$ & $0-508$ & 1,950 & 5 & 12 \\
\hline & KY00-03 (R/V Kaiyo) & July, 2000 & $\mathrm{P}^{*}$ & $35^{\circ} 13^{\prime} \mathrm{N}$ & $139^{\circ} 40^{\prime} \mathrm{E}$ & 606 & - & - & 1 \\
\hline \multirow[t]{2}{*}{ East China Sea } & 2015-05 (T/S Toyoshio-maru) & May, 2015 & ECS2 & $32^{\circ} 45^{\prime} \mathrm{N}$ & $129^{\circ} 30^{\prime} \mathrm{E}$ & $0-86$ & 157 & 0 & 0 \\
\hline & & & ECS8 & $30^{\circ} 46^{\prime} \mathrm{N}$ & $131^{\circ} 35^{\prime} \mathrm{E}$ & $0-472$ & 892 & 1 & 3 \\
\hline western South Pacific & C5441 (R/V Cape Ferguson) & July, 2012 & WSP1 & $15^{\circ} 34^{\prime} \mathrm{S}$ & $145^{\circ} 49^{\prime} \mathrm{E}$ & $0-722$ & 180 & 21 & 2 \\
\hline \multirow[t]{29}{*}{ Mediterranean Sea } & FISHJELLY (R/V Garcia del Cid) & June, 2012 & 1 & $41^{\circ} 04^{\prime} \mathrm{N}$ & $1^{\circ} 24^{\prime} \mathrm{E}$ & $0-74$ & 3,340 & 0 & 0 \\
\hline & & & 3 & $41^{\circ} 06^{\prime} \mathrm{N}$ & $1^{\circ} 50^{\prime} \mathrm{E}$ & $0-37$ & 1,183 & 0 & 0 \\
\hline & & & & & & $2-168$ & 2,907 & 0 & 0 \\
\hline & & & 4 & $40^{\circ} 58^{\prime} \mathrm{N}$ & $2^{\circ} 03^{\prime} \mathrm{E}$ & $0-638$ & 883 & 0 & 0 \\
\hline & & & & & & $2-939$ & 1,282 & 0 & 0 \\
\hline & & & & & & $0-127$ & 3,111 & 0 & 0 \\
\hline & & & & & & $127-988$ & 637 & 0 & 0 \\
\hline & & & & & & 2-966 & 417 & 0 & 0 \\
\hline & & & & & & 0-289 & 559 & 0 & 3 \\
\hline & & & & & & $289-1,023$ & 564 & 0 & 0 \\
\hline & & & & & & 2-818 & 1,787 & 3 & 4 \\
\hline & & July, 2012 & 6 & $41^{\circ} 03^{\prime} \mathrm{N}$ & $1^{\circ} 31^{\prime} \mathrm{E}$ & $0-26$ & 722 & 0 & 0 \\
\hline & & & & & & $2-180$ & 3,376 & 0 & 1 \\
\hline & & & & & & $0-181$ & 4,198 & 0 & 5 \\
\hline & & & & & & $0-134$ & 126 & 0 & 0 \\
\hline & & & & & & $0-112$ & 1,739 & 2 & 3 \\
\hline & & & & & & $2-135$ & 868 & 0 & 0 \\
\hline & & & $\mathrm{J} 2$ & $41^{\circ} 19^{\prime} \mathrm{N}$ & $2^{\circ} 30^{\prime} \mathrm{E}$ & $0-603$ & 2,694 & 7 & 10 \\
\hline & & & & & & $2-580$ & 749 & 1 & 1 \\
\hline & & & $\mathrm{J} 4$ & $41^{\circ} 10^{\prime} \mathrm{N}$ & $2^{\circ} 41^{\prime} \mathrm{E}$ & $0-155$ & 1,190 & 0 & 5 \\
\hline & & & & & & $155-1,014$ & 1,955 & 1 & 2 \\
\hline & & & & & & $2-763$ & 1,021 & 1 & 5 \\
\hline & & & $\mathrm{K} 3$ & $41^{\circ} 21^{\prime} \mathrm{N}$ & $2^{\circ} 36^{\prime} \mathrm{E}$ & $0-272$ & 1,895 & 4 & 6 \\
\hline & & & K4 & $41^{\circ} 17^{\prime} \mathrm{N}$ & $2^{\circ} 42^{\prime} \mathrm{E}$ & $0-673$ & 1,986 & 1 & 5 \\
\hline & & & & & & $2-339$ & 1,659 & 1 & 2 \\
\hline & & & $\mathrm{R} 4$ & $41^{\circ} 49^{\prime} \mathrm{N}$ & $3^{\circ} 34^{\prime} \mathrm{E}$ & $0-26$ & 239 & 6 & 0 \\
\hline & & & & & & $26-864$ & 1,239 & 10 & 4 \\
\hline & & & & & & $0-1,014$ & 1,030 & 0 & 0 \\
\hline & & & & & & total & 48,754 & 65 & 117 \\
\hline
\end{tabular}

*: The underwater video-camera survey was conducted at this station.

\section{Results}

A total of 48,754 images, including those of 65 radiolarians and 117 phaeodarians, were obtained by the VPR and underwater camera, from a variety of different depths and stations. A subset of these images is shown in Fig. 2, and detailed information is listed in Table 2. Radiolarians of three orders (Acantharia, Spumellaria and Collodaria) were detected, whereas no species belonging to the orders Nassellaria or Taxopodia were recorded. Four phaeodarian orders were recognized (Phaeocystida, Phaeosphaerida, Phaeocalpida and Phaeodendrida), and three taxa were identified to the family level (Aulacanthidae, Tuscaroridae and Coelodendridae). Colonies were observed for one radiolarian order (Collodaria) and three phaeodarian taxa (Phaeosphaerida, Tuscaroridae and Coelodendridae). The colonies of Phaeosphaerida observed in this study contained one empty skeleton (lattice shell) that lacked the internal soft parts (malacoma), including the central capsule and phaeodium (Fig. 2L-M). The images of radiolarians were generally taken in layers shallower than $100 \mathrm{~m}$ depth (Table 2), but solitary collodarians were observed also in the deeper zones. Phaeodarians were mainly detected below $100 \mathrm{~m}$ depth (Table 2). 

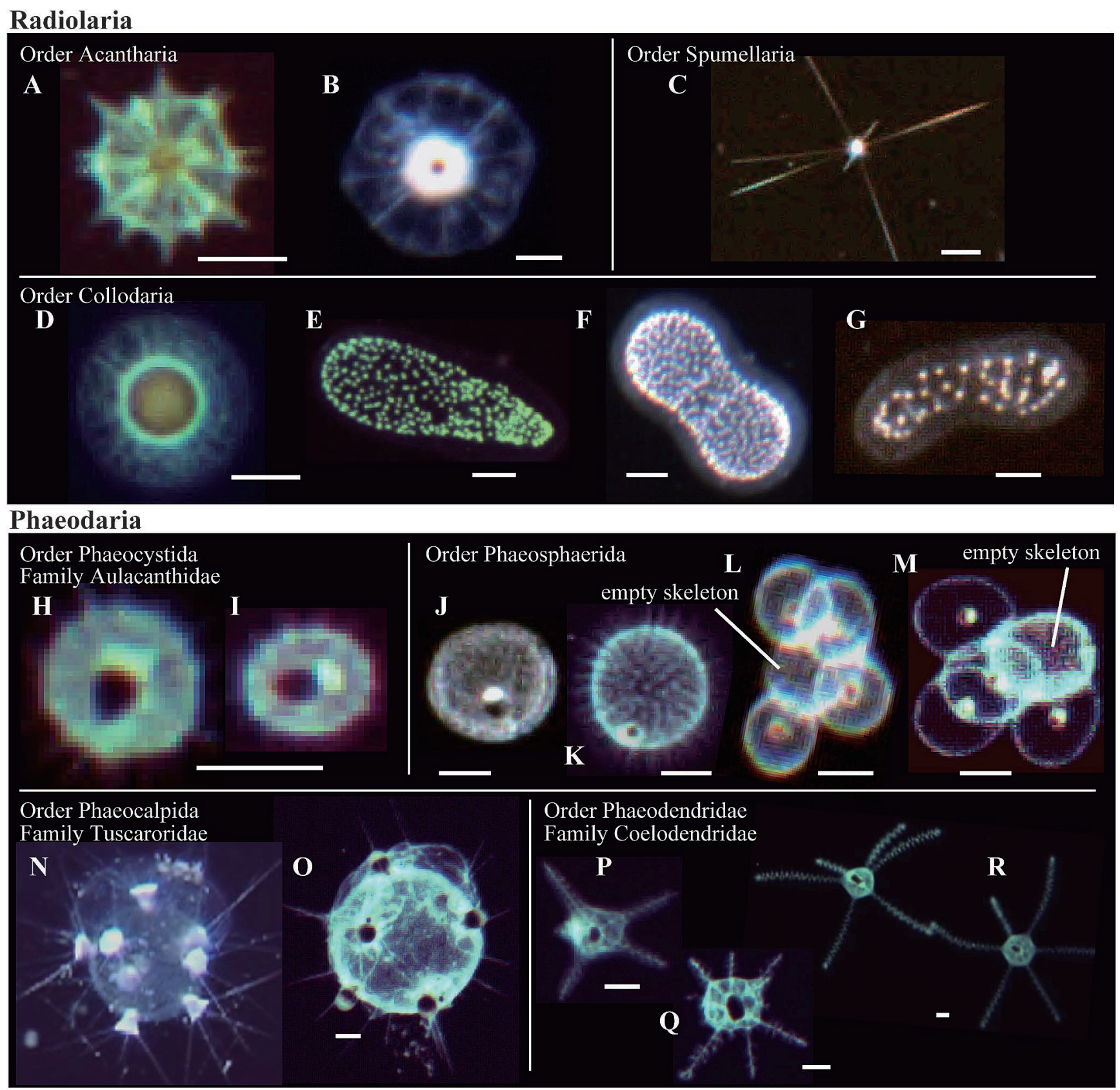

Fig. 2. A-VPR images of radiolarians $(A-G)$ and phaeodarians $(H-Q)$. The detailed information for each image is shown in Table 2 . Note that image $\mathrm{N}$ is a framegrab from an underwater high-definition video-camera attached to the ROV Hyper-Dolphin. All scale bars are $1,000 \mu \mathrm{m}$.

\section{Discussion}

A list of identification criteria for radiolarians and phaeodarians to be used in optics-based surveys is presented, based on the 65 radiolarian images and 117 phaeodarian images obtained in this study (Table 1) and the morphological criteria laid out in the current classification system (Table 3). Radiolarian-like images obtained by optics-based surveys can be categorized into nine groups in future studies: the eight orders and families treated in this study and "other radiolarian-like plankton".

\section{Radiolaria}

The species of the three radiolarian orders recognized in this study (Acantharia, Spumellaria and Collodaria) are generally larger ( $>$ ca. $400 \mu \mathrm{m}$ in diameter) than the other orders (Nassellaria or Taxopodia). Most of the species belonging to these two orders are so small $(<400 \mu \mathrm{m})$ that the A-VPR used in this study would have been unable to detect them, though these two orders are important radiolarian groups from the viewpoint of species numbers (Nassellaria, Suzuki \& Not 2015) and/or abundances (Taxopo- 
Table 2. Detailed information on the A-VPR images shown in Fig. 2.

\begin{tabular}{|c|c|c|c|c|c|c|c|}
\hline Image & Order & Family & Mode & Sea area & Station & Depth (m) & File name** \\
\hline \multicolumn{8}{|c|}{ Radiolaria } \\
\hline A & Acantharia & - & solitary & Mediterranean Sea & $\mathrm{J} 2$ & 61.9 & ffr.08456835.jpg \\
\hline $\mathrm{B}$ & Acantharia & - & solitary & western South Pacific & WSP1 & 62 & ffr.37827123.jpg \\
\hline $\mathrm{C}$ & Spumellaria & - & solitary & East China Sea & ECS8 & 24.5 & ffr.10266069.jpg \\
\hline $\mathrm{D}$ & Collodaria & - & solitary & Mediterranean Sea & 4 & 80.3 & ffr.44440992.jpg \\
\hline $\mathrm{E}$ & Collodaria & - & colonial & Mediterranean Sea & 6 & 7.1 & ffr.31220293.jpg \\
\hline $\mathrm{F}$ & Collodaria & - & colonial & western South Pacific & WSP1 & 6.6 & ffr.38003153.jpg \\
\hline G & Collodaria & - & colonial & western South Pacific & WSP1 & 87.2 & ffr.60297455.jpg \\
\hline \multicolumn{8}{|c|}{ Phaeodaria } \\
\hline $\mathrm{H}$ & Phaeocystida & Aulacanthidae & solitary & Mediterranean Sea & $\mathrm{R} 4$ & 405.1 & ffr.16354548.jpg \\
\hline I & Phaeocystida & Aulacanthidae & solitary & Mediterranean Sea & $\mathrm{J} 4$ & 87.4 & ffr.62383833.jpg \\
\hline $\mathrm{J}$ & Phaeosphaerida & - & solitary & East China Sea & ECS8 & 470.9 & ffr.13138452.jpg \\
\hline $\mathrm{K}$ & Phaeosphaerida & - & solitary & Mediterranean Sea & $\mathrm{J} 4$ & 252.8 & ffr.57969132.jpg \\
\hline $\mathrm{L}$ & Phaeosphaerida & - & colonial & western South Pacific & WSP1 & 243 & ffr.63309026.jpg \\
\hline $\mathrm{M}$ & Phaeosphaerida & - & colonial & western North Pacific & WNP2 & 470.3 & ffr.38805061.jpg \\
\hline $\mathrm{N}^{*}$ & Phaeocalpida & Tuscaroridae & colonial & western North Pacific & $\mathrm{P}^{*}$ & 606 & HPD0014-TC10303209DF.tif \\
\hline $\mathrm{O}$ & Phaeocalpida & Tuscaroridae & colonial & western North Pacific & WNP1 & 150.7 & ffr.35453537.jpg \\
\hline $\mathrm{P}$ & Phaeodendrida & Coelodendridae & solitary & Mediterranean Sea & $\mathrm{J} 2$ & 479.7 & ffr.10179548.jpg \\
\hline Q & Phaeodendrida & Coelodendridae & solitary & Mediterranean Sea & 4 & 665.4 & ffr.43464238.jpg \\
\hline $\mathrm{R}$ & Phaeodendrida & Coelodendridae & colonial & Mediterranean Sea & $\mathrm{R} 4$ & 44.99 & ffr.27234635.jpg \\
\hline
\end{tabular}

*: This image is a framegrab from an underwater video-camera attached to the ROV Hyper-Dolphin. The original video file is available on the JAMSTEC E-library of Deep-sea Images (J-EDI): http://www.godac.jamstec.go.jp/jedi/static_player/j/HPD0014OTHSV10_01154690

**: Original files are available as Supplementary material (except image N) at http://www.godac.jamstec.go.jp/catalog/data_catalog/meta dataDisp/Nakamura et al 2017?lang=en

Occurrence records have been submitted to the Biological Information System for Marine Life (BISMaL)

Table 3. Identification criteria for "radiolarian-like plankton" during optics-based surveys.

\begin{tabular}{|c|c|c|c|c|c|}
\hline Identification criteria & Higher taxon & Identification criteria & Order & Family & Fig. 2 \\
\hline \multirow{4}{*}{$\begin{array}{l}\text { Radially symmetrical } \\
\text { cell with a concentric } \\
\text { circle, but no (or small) } \\
\text { dark part. }\end{array}$} & \multirow{4}{*}{ Radiolaria } & Spherical cell with 20 straight regularly-arranged spicules (following "Müller's law"). & Acantharia & - & A, B \\
\hline & & $\begin{array}{l}\text { Spherical cell with radial spines of variable numbers (the arrangement of the } \\
\text { spines does not follow "Müller's law"). }\end{array}$ & Spumellaria & - & $\mathrm{C}$ \\
\hline & & $\begin{array}{l}\text { Large spherical cell ( } 200-600 \mu \mathrm{m} \text { in diameter) surrounded by gelatinous matter or } \\
\text { bubble-like structures. }\end{array}$ & $\begin{array}{r}\text { Collodaria } \\
\text { (solitary) }\end{array}$ & - & $\mathrm{D}$ \\
\hline & & $\begin{array}{l}\text { Several to hundreds of small cells (white, yellowish or greenish dots) covered } \\
\text { with transparent or whitish gelatinous matter. }\end{array}$ & $\begin{array}{r}\text { Collodaria } \\
\text { (colonial) }\end{array}$ & - & $\mathrm{E}-\mathrm{G}$ \\
\hline \multirow{4}{*}{$\begin{array}{l}\text { Cell not radially sym- } \\
\text { metrical, containing } \\
\text { one or several bright } \\
\text { parts (central capsule) } \\
\text { and relatively large } \\
\text { dark part (phaeodium). }\end{array}$} & \multirow[t]{4}{*}{ Phaeodaria } & $\begin{array}{l}\text { Spherical cell without geometric meshwork, with irregularly- arranged short } \\
\text { spines from the center. }\end{array}$ & Phaeocystida & Aulacanthidae & $\mathrm{H}, \mathrm{I}$ \\
\hline & & $\begin{array}{l}\text { Sphaerical cell with geometric meshwork (latticed shell), with irregularly-arranged } \\
\text { short spines from the surface, occasionally forming a colony of } 2-5 \text { cells. }\end{array}$ & Phaeosphaerida & - & $\mathrm{J}-\mathrm{M}$ \\
\hline & & $\begin{array}{l}\text { Colony composed of a large empty sphere surrounded by } 7-10 \text { octopus-like cells } \\
\text { with several spines. }\end{array}$ & Phaeocalpida & Tuscaroridae & $\mathrm{N}, \mathrm{O}$ \\
\hline & & $\begin{array}{l}\text { Spherical or angulate cell with several long branch-like extensions (styles) from } \\
\text { the center, occasionally forming a colony of } 2-3 \text { cells. }\end{array}$ & Phaeodendrida & Coelodendridae & $\mathrm{P}-\mathrm{R}$ \\
\hline
\end{tabular}

dia, Tan et al. 1978).

\section{1-1. Acantharia}

Radially symmetrical structures characterize both Spumellaria and Acantharia, and these two groups are often confused with each other. Acantharians can, however, be distinguished from spumellarians by their regularly-arranged spicules. Most of the species belonging to this order have a skeleton with 20 straight spicules. Some species have 10 spicules that intersect at the center of the cell, making it seem as if they have 20 spicules. Acantharians consist of nine molecular phylogenetic clades (Decelle \& 
Not 2015), and these clades can morphologically be distinguished only by observing the anatomy of their central skeletal part and the presence/absence of algal symbionts. Such morphological structures are impossible to observe in the present VPR images, therefore this device is not the right tool to precisely identify acantharians.

Acantharians of two different morphotypes were recorded in this study, but the resolution of the VPR did not allow them to be identified to the family level. Some acantharians harbor algal symbionts (Rost 1995, Decelle \& Not 2015), and it is possible to distinguish them by applying light excitation. The lower taxonomic ranks of Acantharia could be identified by optics-based gear using light excitation in future studies.

\section{1-2. Spumellaria}

The skeleton of spumellarians is also radially symmetrical in general, but the number of spicules is variable, and their position is not as geometric as that of acantharians.

Extant Spumellaria consist of ca. 380 species (Suzuki \& Not 2015), but due to their small cell size only one species was identified in this study. Image C (Fig. 2) was identified as Spongosphaera streptacantha Haeckel (Spongosphaeridae). This species is characterized by 6-9 long straight radial spines ( $>$ several millimeters) and a very small cytoplasmic part. The size ratio of the cytoplasmic part to the radial spines is 1 to 8 (or more). The present species is commonly found in warm waters, and its morphological variation and taxonomic criteria are well-documented (Anderson 1983, Kurihara \& Matsuoka 2004).

\section{1-3. Collodaria}

Collodaria include two ecological types: colonial and solitary. Colonial collodarians usually form a colony of several to hundreds of cells (which look like white or yellowish white dots) covered by transparent (or whitish) gelatinous matter. Their colony sizes range from a few millimeters to several meters (Swanberg 1983). The solitary collodarians have large (200-600 $\mu \mathrm{m}$ in diameter) spherical shells surrounded with gelatinous or bubble-like matter.

Colonial and solitary collodarians usually possess algal symbionts, and they are seen in the euphotic zone where photosynthesis is possible (Suzuki \& Not 2015). Yet, both types also occur below the euphotic zone (Trégouboff 1956,1958 \& 1959), as is the case in this study (images D and $\mathrm{G}$ in Table 2 and Fig. 2). Collodarians are thought to reproduce below the euphotic zone (e.g. Anderson 1983), and this may be one reason why they are occasionally found in deeper layers.

Solitary collodarians could be a polyphyletic group, according to the branching pattern of collodarians in a DNAbased phylogenetic tree, suggesting that both solitary and colonial types are a part of the same life cycle (Biard et al. 2015). We therefore suggest simply treating them as "solitary" and/or "colonial" collodarians. Despite tremendous efforts, very little data are available to estimate the abun- dance of collodarians (Swanberg 1974). In situ imaging has proved to be a useful tool to quantify members of this group (Dennett et al 2002, Biard et al 2016).

\section{Phaeodaria}

In optics-based surveys, phaeodarians are characterized by a cell that is not radially symmetrical and by the presence of a large dark area within the cell. This dark part is, in most cases, the phaeodium. This "phaeodium", a mass of brown aggregated particles, and "central capsule", a capsule-like structure containing the nuclei, are the most important identification criteria for Phaeodaria (Haeckel 1887).

Phaeodaria include seven orders according to the latest classification system: Phaeocystida, Phaeosphaerida, Phaeocalpida, Phaeodendrida, Phaeoconchida, Phaeogromida and Phaeogymnocellida (Takahashi \& Anderson 2002). However, only the first four orders were detected in this study, because of their large cell size $(>500 \mu \mathrm{m})$, as was also the case with radiolarians.

\section{2-1. Aulacanthidae}

Phaeodarians belonging to the order Phaeocystida are easily identified to the family level. This order includes two families: Astracanthidae and Aulacanthidae. The latter family is generally larger, and more amenable to detection during optics-based surveys. In order to identify them to lower taxa, such as species or genus, it is necessary to examine the form of the irregularly-arranged short spines called "radial spines".

All of the Phaeocystida phaeodarians found in this study were species belonging to the Aulacanthidae, according to their spherical shell, the form of the spines and the large cell sizes. The authors have occasionally observed some species of this family connected to each other and forming a colony-like mass in fresh plankton net samples from the western North Pacific (data not shown). However, only single individuals were observed in situ during this study, and further optics-based surveys are necessary to clarify the specifics of their colony formation.

\section{2-2. Phaeosphaerida}

The order Phaeosphaerida has a spherical skeleton with a geometric meshwork called a "lattice shell" and has irregularly arranged short spines extending from the surface of the shell. They sometimes form colonies of 2-5 cells. This order is composed of three families, and these families are distinguishable from each other by the fine structure of the geometric meshwork, which is impossible to observe with the A-VPR at current resolutions.

Naturally-occurring colonies of this order were recognized in situ in the present study (Fig. 2L, M). Their colonies have also been photographed in other optics-based surveys (Ichikawa 2008, Biard et al. 2016). Previous studies based on plankton net sampling examined aggregated specimens (e.g. Reshetnyak 1966, Tibbs 1976), but it 
was difficult to determine whether they were colonial or solitary. The optics-based surveys, however, have allowed us to confirm the existence of colonies in their natural environment. A colony with an empty skeleton was also recorded by another VPR survey (Ichikawa 2008). The existence of this empty skeleton is probably related to their mechanisms of colony formation or style of reproduction.

\section{2-3. Tuscaroridae}

The order Phaeocalpida contains five families with differing skeletal structures and cell sizes. Of these families, we can normally observe the family Tuscaroridae during optics-based surveys, undoubtedly because the cell size is larger than those of the other families. The species of this family have an octopus-like skeleton, and they make a colony composed of one empty sphere surrounded by $6-10$ individuals. The colonies observed in this study probably belong to two different species according to the morphology of the individuals (Fig 2N, O).

The existence of a colony with an empty skeleton is similar to the situation observed in the Phaeosphaerida, where a colony including a skeleton without interior protoplasm was also imaged (Fig 2L, M). These two groups are phylogenetically close, according to the branching pattern in the phylogenetic tree based on an 18S rDNA analysis (Nakamura et al. 2015), and the presence of a colony with an empty skeleton presumably reflects the genetic relationship between the two groups.

\section{2-4. Coelodendridae}

The order Phaeodendrida consists of a single family, Coelodendridae (Takahashi \& Anderson 2002). The skeleton of this family possesses several long branch-like extensions called "styles" (Nakamura \& Suzuki 2015a), by which 2-3 individuals are occasionally connected together forming a colony (Fig. 2R, Swanberg et al. 1986, Extended Data Figure 2c in Biard et al. 2016). The central capsule of this family is covered by a skeleton called the "inner shell", and this structure appears black in VPR images (Fig. 2P-R).

Although their morphology differed from previously described species, images P, Q and R (Fig. 2) were classified as coelodendrids. Similar individuals and colonies belonging to this family have also been photographed during previous in situ optics-based surveys (Ichikawa 2008, Biard et al. 2016).

Although the precise vertical distributions of radiolarians and phaeodarians have not been well-clarified, the present results reflect the prevailing assumption that radiolarians with algal symbionts occur mainly in the layers shallower than the zones where phaeodarians live (Takahashi \& Anderson 2002, Suzuki \& Not 2015, Nakamura \& Suzuki 2015a, b). Future studies should collect more optics-based data and further clarify the vertical distribution patterns of these unicellular zooplankton.

\section{Future Directions}

Increases in the resolution of optics-based survey tools will undoubtedly contribute greatly to our knowledge of the in situ ecology of unicellular zooplankton. Higher resolution usually comes at a tradeoff with reduced imaged volumes, which is problematic for surveys of plankton that occur at low concentrations. The Japan Agency for Marine-Earth Science and Technology (JAMSTEC) is currently developing several new types of optical survey tools, and these systems are expected to be of great value for quantitative surveys of various zooplankton that are impossible to image and identify with current optical systems.

\section{Acknowledgements}

We thank Drs. Susumu Ohtsuka (Hiroshima University), Ana Sabates and Veronica Fuentes (CMIMA-CSIC), Mike Hall (AIMS), and Akio Tamaki (Nagasaki University). We are grateful to the captains, crews and scientific teams of the MR11-03 cruise aboard the R/V Mirai, of the KY0003 cruise aboard the R/V Kaiyo, of the 2015-05 cruise aboard the T/S Toyoshio-maru, of the FISHJELLY cruise aboard the R/V García del Cid, and of the C5441 cruise aboard the R/V Cape Ferguson. Thanks are also due to Dr. Ichiro Imai and the members of the Plankton Laboratory of Hokkaido University for their kind technical advice and to Keisuke Sunahara (JAMSTEC) for technical assistance. Constructive comments by two anonymous reviewers greatly improved the manuscript. This study was financially supported by Grant-in-Aid for JSPS Fellows (no. 26-2889, Y. Nakamura), Mikimoto Fund for Marine Ecology (2016, Y. Nakamura), JSPS KAKENHI (no. 24248032), FISHJELLY project (MAR-CTM2010-18874) and JST grant CREST, the fund for Interdisciplinary Collaborative Research by the Atmosphere and Ocean Research Institute, University of Tokyo.

\section{References}

Adl SM, Simpson AG, Lane CE, Lukeš J, Bass D, Bowser SS, Brown MW, Burki F, Dunthorn M, Hampl V, Heiss A, Hoppenrath M, Lara E, Le Gall L, Lynn DH, McManus H, Mitchell EA, Mozley-Stanridge SE, Parfrey LW, Pawlowski J, Rueckert S, Shadwick RS, Schoch CL, Smirnov A, Spiegel FW (2012) The revised classification of eukaryotes. J Eukaryot Microbiol 59: 429-493.

Anderson OR (1983) Radiolaria. Springer, New York, 355 pp.

Antia AN, Bauerfeind E, Boudungen BV \& Zeller U (1993) Abundance, encystment and sedimentation of Acantharia during autumn 1990 in the East Greenland Sea. J Plankton Res 15: 99-114.

Benfield MC, Davis CS, Wiebe PH, Gallager SM, Lough RG, Copley NJ (1996) Video Plankton Recorder estimates of copepod, pteropod and larvacean distributions from a stratified 
region of Georges Bank with comparative measurements from a MOCNESS sampler. Deep-Sea Res II 43: 1925-1945.

Benfield MC, Grosjean P, Culverhouse PF, Irigoien X, Sieracki ME, Lopez-Urrutia A, Dam HG, Hu Q, Davis CS, Hansen A, Pilskaln CH, Riseman EM, Schultz H, Utgoff PE, Gorsky G (2007) RAPID: Research on Automated Plankton Identification. Oceanography 20: 172-187.

Biard T, Pillet L, Decelle J, Poirier C, Suzuki N, Not F (2015) Towards an integrative morpho-molecular classification of the Collodaria (Polycystinea, Radiolaria). Protist 166: 374-388.

Biard T, Stemmann L, Picheral M, Mayot N, Vandromme P, Hauss H, Gorsky G, Guidi L, Kiko R, Not F (2016) In situ imaging reveals the biomass of giant protists in the global ocean. Nature 532: 504-507.

Boltovskoy D, Kling SA, Takahashi K, Bjørklund K (2010) World atlas of distribution of Recent Polycystina (Radiolaria). Palaeontol Electron 13: 1-230.

Decelle J, Not F (2015) Acantharia. In: eLS (ed eLS). John Wiley \& Sons, Ltd, Chichester, doi: 10.1002/9780470015902. a0002102.pub2.

Dennett MR, Caron DA, Michaels AE, Church M, Gallager SM \& Davis CS (2002) Video Plankton Recorder reveals high abundance of colonial Radiolaria in surface waters of the central north Pacific. J Plankton Res 24: 797-805.

Haeckel E (1887) Report on the Radiolaria collected by H.M.S. Challenger during the years 1873-1876. Rep Sci Res Voyage HMS Challenger 1873-1876, Zool 18: 1-1803.

Howe AT, Bass D, Scoble JM, Lewis R, Vickerman, K Arndt H, Cavalier-Smith T (2011) Novel cultured protists identify deep-branching environmental DNA clades of Cercozoa: new genera Tremula, Micrometopion, Minimassisteria, Nudifila, Peregrinia. Protist 162: 332-372.

Ichikawa T (2008) Analysis of the community structure of mesozooplankton in the Oyashio and Transition Zone using Video Plankton Recorder (VPRII). Bull Fish Res Agen 24: 23-104. (in Japanese with English abstract)

Jacobsen HP, Norrbin MF (2009) Fine-scale layer of hydromedusae is revealed by video plankton recorder (VPR) in a semienclosed bay in northern Norway. Mar Ecol Prog Ser 380: 129-135.

Kurihara T, Matsuoka A (2004) Shell structure and morphologic variation in Spongosphaera streptacantha Haeckel (Spumellaria, Radiolaria). Sci Rep Niigata Univ (Geol) 19: 35-48.

Lampitt RS, Salter I, Johns D (2009) Radiolaria: Major exporters of organic carbon to the deep ocean. Global Biogeochem Cycles 23: GB1010, doi:10.1029/2008GB003221.

Lindsay DJ, Yamaguchi A, Grossmann MM, Nishikawa J, Sabates A, Fuentes V, Hall M, Sunahara K, Yamamoto H (2014) Vertical profiles of marine particulates: a step towards global scale comparisons using an Autonomous Visual Plankton Recorder Bull Plankton Soc Japan 61: 1-8.

Motoyama I, Yamada Y, Hoshiba M, Itaki T (2016) Radiolarian assemblages in surface sediments of the Japan Sea. Paleontol Res 20: 176-206.

Michaels AF (1988) Vertical distribution of abundance of Acantharia and their symbionts. Mar Biol 97: 559-569.

Müller J (1856) Über die Thalassicollen, Polycystinen und Acanthometren des Mittelmeeres. Monatsber Königl Preuß Akad
Wissensch Berlin 1856: 474-503.

Müller J (1859) Über die Thalassicollen, Polycystinen und Acanthometren des Mittelmeeres. Abhandl Königl Akad Wissensch Berlin 1859: 1-62.

Nakamura Y, Imai I, Yamaguchi A, Tuji A, Suzuki N (2013) Aulographis japonica sp. nov. (Phaeodaria, Aulacanthida, Aulacanthidae), an abundant zooplankton in the deep sea of the Sea of Japan. Plankton Benthos Res 8: 107-115.

Nakamura Y, Imai I, Yamaguchi A, Tuji A, Not F, Suzuki N (2015) Molecular phylogeny of the widely distributed marine protists, Phaeodaria (Rhizaria, Cercozoa). Protist 166: 363373.

Nakamura Y, Suzuki N (2015a) Chapter 9 Phaeodaria: Diverse marine cercozoans of world-wide distribution. In: Ohtsuka S, Suzaki T, Horiguchi T, Suzuki N, Not F (eds.), Marine Protists Diversity and Dynamics, Springer Tokyo: 223-249.

Nakamura Y, Suzuki N (2015b) Biology of widely distributed marine protists, Phaeodaria (Rhizaria, Cercozoa). Bull Plankton Soc Japan 62: 110-122. (in Japanese with English abstract)

Nikolaev SI, Berney C, Fahrni JF, Bolivar I, Polet S, Mylnikov AP, Aleshin VV, Petrov NB, Pawlowski J (2004) The twilight of Heliozoa and rise of Rhizaria, an emerging supergroup of amoeboid eukaryotes. PNAS 101: 8066-8071.

Polet S, Berney C, Fahrni J, Pawlowski J (2004) Small-subunit ribosomal RNA gene sequences of Phaeodaria challenge the monophyly of Haeckel's Radiolaria. Protist 155: 53-63.

Remsen A, Hopkins TL \& Samson S (2004) What you see is not what you catch: a comparison of concurrently collected net, Optical Plankton Counter, and Shadowed Image Particle Profiling Evaluation Recorder data from the northeast Gulf of Mexico. Deep Sea Res I 51: 129-151.

Reshetnyak VV (1966) Glubokovodnye radiolyarii feodaria severozapadnoy chasti, Tikhogo Okeana. Fauna SSSR 94: 1-208.

Riemann F (1989) Gelatinous phytoplankton detritus aggregates on the Atlantic deep-sea bed. Mar Biol 100: 533-539.

Rost FWD (1995) Fluorescence Microscopy, Volume 2. Cambridge University Press, Cambridge, 457 pp.

Sierra R, Matz MV, Aglyamova G, Pillet L, Decelle J, Not F, de Vargas C, Pawlowski J (2013) Deep relationships of Rhizaria revealed by phylogenomics: A farewell to Haeckel's Radiolaria. Mol Phyl Evol 67: 53-59.

Steinberg DK, Cope JS, Wilson SE, Kobari T (2008) A comparison of mesopelagic mesozooplankton community structure in the subtropical and subarctic North Pacific Ocean. Deep-Sea Res II 55: 1615-1635.

Suzuki N, Aita Y (2011a) Topics on the spatial distributions, standing stocks, and symbiosis of living Radiolaria (Rhizaria, Protoctista). Bull Plankton Soc Japan 58: 40-48. (in Japanese with English abstract)

Suzuki N, Aita Y (2011b) Radiolaria: achievements and unresolved issues: taxonomy and cytology. Plankton Benthos Res 6: 69-91.

Suzuki N, Not F (2015) Chapter 8 Biology and Ecology of Radiolaria. In: Ohtsuka S, Suzaki T, Horiguchi T, Suzuki N, Not F (eds.), Marine Protists Diversity and Dynamics, Springer Tokyo, pp. 179-222.

Swanberg NR (1974) The ecology of colonial radiolarians: Their 
colony morphology, trophic interactions and associations, behavior, distribution, and the photosynthesis of their symbionts. PhD thesis. Massachusetts Inst Tech \& Woods Hole Oceanogr Inst, USA.

Swanberg NR (1983) The trophic role of colonial Radiolaria in oligotrophic oceanic environments. Limnol Oceanogr 28: 655-666.

Swanberg NR, Bennet P, Lindsey JL \& Anderson OR (1986) The biology of a coelodendrid: a mesopelagic phaeodarian radiolarian. Deep-Sea Res 33: 15-25.

Takahashi K (1991) Radiolaria: flux, ecology, and taxonomy in the Pacific and Atlantic. Ocean Biocoenosis Series 3. Woods Hole Oceanographic Institution Press, Woods Hole, 303 pp.

Takahashi K, Anderson OR (2002) Class Phaeodaria. In: Lee JJ, Leedale GF and Bradbury P (eds) The second illustrated guide to the protozoa. Society of Protozoologists, Lawrence, pp. 981-994.
Tan Z, Gao H, Su X (1978) The quantitative distribution of Sticholonche zanclea in the western part of the East China Sea. Oceanol Limnol Sinica 9: 59-66. (in Chinese with English abstract)

Tibbs JF (1976) On some planktonic protozoa taken from the track of Drift Station ARLIS I, 1960-1961. Arctic Inst North Am 20: 247-254.

Trégouboff G (1956) Prospection biologique sous-marine dans la région de Villefranche-sur-Mer en juin 1956. Bull Inst Océan 1085: 1-24.

Trégouboff G (1958) Prospection biologique sous-marine dans la région de Villefranche-sur-Mer au cours de l'année 1957. 1. Plongée en bathyscaphe. Bulle Inst Océan 1117: 1-37.

Trégouboff G (1959) Prospection biologique sous-marine dans la région de Villefranche-sur-Mer en mars 1959. Bull Inst Océan 1156: 1-18. 